\title{
Cannabis body packing in Greenland
}

\author{
Martin Ekdahl, Luit Penninga
}

Ilulissat Hospital, Avannaa Health Region, Ilulissat, Greenland

\section{Correspondence to} Dr Luit Penninga, LP@ctu.dk

Accepted 3 July 2019

\section{DESCRIPTION}

Internal concealment of illegal drugs through body packing, pushing or stuffing, after crossing international borders is commonly encountered in Greenland, similar to many other emergency departments around the world. ${ }^{12}$ In Greenland, body packing primarily involves cannabis.

Here we report about a woman who was taken directly from the airport to our hospital by police officers due to high suspicion of drug trafficking. The patient was rather silent and made little eye contact during most of the consultation. The patient was gently asked to present any drugs, which she refused. She also refused a clinical examination but agreed to let us obtain an abdominal X-ray (AXR). The AXR showed a package in the rectum (figure 1). After explaining the AXR findings to her, she calmly removed a package containing cannabis from her rectum (figure 2). Then she confessed drug trafficking and was taken to custody by the local police officers. Six months later, I talked with the patient about the incident during a regular visit to the hospital. She told me that she was ashamed of what she had done and regretted her actions.

Body packers often represent a combination of medical, legal, ethical and social aspects, which put the doctor in the dilemma of both caring for the patient and at the same time awareness of the justice system. ${ }^{3}$ There is no golden standard for image detection. AXR is a valuable diagnostic tool

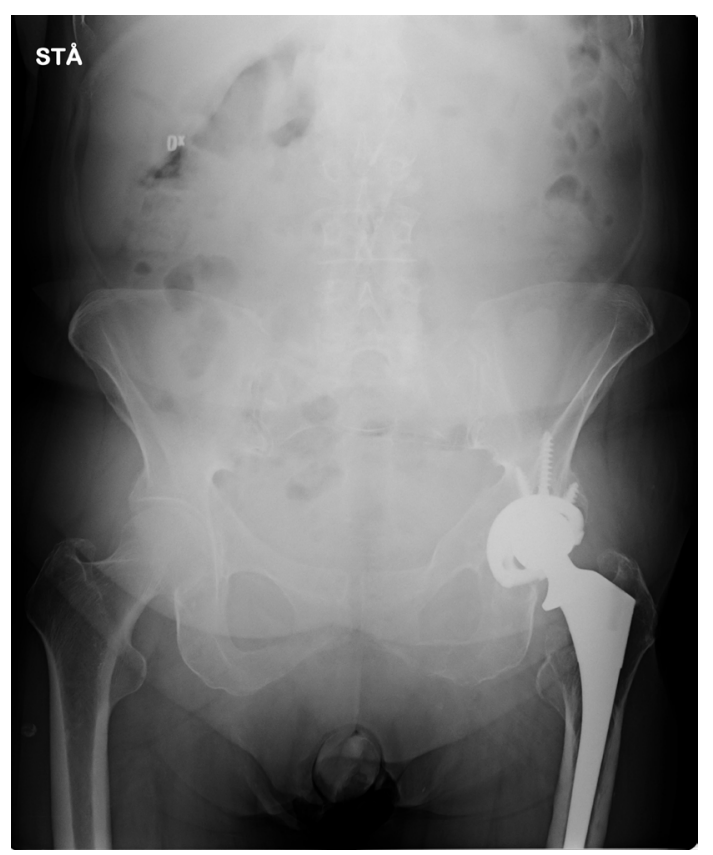

Figure 1 Abdominal X-ray showing a cannabis package in the rectum.

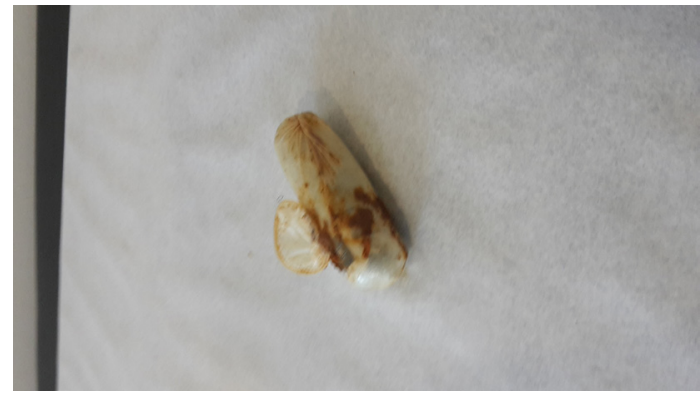

Figure 2 Cannabis package wrapped in a condom.

in detection of foreign bodies. The AXR is diagnostic if positive, though it is not sensitive $(47 \%-$ 95\%) enough to completely rule out abdominal body packing. CT scanning, ultrasound scanning and MR scanning may have a role in detection of body packing, though false negative abdominal CT scans have been reported. ${ }^{23}$ A thoroughly intimate body search includes mouth, nostrils, ears, umbilicus, foreskin, rectum and vagina. ${ }^{2}$

Body packers can be women, men and children who present themselves in a number of ways. The majority of patients are asymptomatic. Symptomatic patients can present with abdominal obstruction or with the 'body packer syndrome' caused by poisoning after a packet rupture. Patients may need acute surgery to remove the packages for both these reasons. ${ }^{12}$ Poisoning is mostly caused by cocaine or heroin. ${ }^{2}$ Cocaine intoxication presents itself with agitation, sweating, dilated pupils, hyperthermia, tachycardia and hypertension, or in case of more severe seizures, myocardial infarction and arrhythmias. Heroin can lead to fall in consciousness, respiratory depression, pinpoint pupils, decreased bowel sounds. ${ }^{2}$

Asymptomatic patients can be treated conservatively with low risk of complications. ${ }^{12}$ Mild oral laxatives can be used. ${ }^{2}$

It is worth to mention that low-quality packages (condoms, toy balloons) filled with loose powder and tied with bad knots (type 1 in McCarron and Wood classification system for drug packets) are rare (prevalence 9\%), but low-quality packages are strongly associated with complications (prevalence $62.5 \%$ ). Therefore, it is important to get information about content, quality and number of packages (up to 200 packages have been seen). Mild oral laxatives may be given if constipated. It is important to remember that international travellers who suddenly become ill shall be suspected for internal drug carriage. ${ }^{12}$

Contributors LP and ME had the idea. ME prepared the manuscript. LP critically revised the manuscript. ME and LP approved the final version of the manuscript. 


\section{Learning points}

'Body packing syndrome' should be suspected in international travellers who become ill.

- Cannabis is the most common drug seen in body packers in Greenland, while cocaine and heroin are the most common drugs seen in body packers worldwide.

- Asymptomatic patients have little risk for complications. Symptomatic patients may require intensive care treatment and surgery.
Funding The authors have not declared a specific grant for this research from any funding agency in the public, commercial or not-for-profit sectors.

Competing interests None declared.

Patient consent for publication Obtained.

Provenance and peer review Not commissioned; externally peer reviewed.

\section{REFERENCES}

1 Beckley I, Ansari NA, Khwaja HA, et al. Clinical management of cocaine body packers: the Hillingdon experience. Can J Surg 2009;52:417-21.

2 Booker RJ, Smith JE, Rodger MP, Packers RMP. Packers, pushers and stuffersmanaging patients with concealed drugs in UK emergency departments: a clinical and medicolegal review. Emerg Med J 2009;26:316-20.

3 Smith JE, Hall EJ. The use of plain abdominal $x$ rays in the emergency department. Emerg Med J 2009;26:160-3.

Copyright 2019 BMJ Publishing Group. All rights reserved. For permission to reuse any of this content visit

https://www.bmj.com/company/products-services/rights-and-licensing/permissions/

BMJ Case Report Fellows may re-use this article for personal use and teaching without any further permission.

Become a Fellow of BMJ Case Reports today and you can:

- Submit as many cases as you like

- Enjoy fast sympathetic peer review and rapid publication of accepted articles

- Access all the published articles

- Re-use any of the published material for personal use and teaching without further permission

Customer Service

If you have any further queries about your subscription, please contact our customer services team on +44 (0) 2071111105 or via email at support@bmj.com.

Visit casereports.bmj.com for more articles like this and to become a Fellow 